\title{
Chapter 7 \\ Middle School Climate Change Mitigation and Adaptation Curriculum in the United States: Peers Lead Peers Through Change and Action
}

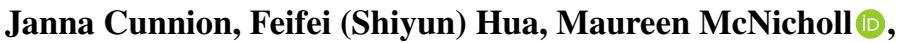 \\ and Sandra Ospina 1
}

\begin{abstract}
While the previous chapters of this book tackle reforms in existing, established national programs, this chapter is an emergent proposition to a change in policy at local school district levels in the United States. Change is dependent on and influenced by the educational ecosystem around the student which includes such stakeholders as parents, teachers, teacher preparation programs, community groups, curriculum and textbook developers, businesses, universities, local and federal agencies, and policy leaders. The criteria for what makes a climate change curriculum "effective" are difficult to name: first, because the subject itself is divisive, and second because humankind has not yet fully understood all there is to know about tackling climate change. Thus, in this chapter, a normative pro stance is taken in support of climate change education, as the need to implement climate change education in school echoes UNESCO's notion that climate education "is crucial to promote climate action. It helps people understand so they can address the impacts of the climate crisis, empowering them with the knowledge, skills, values, and attitudes needed to act as agents of change (Education for climate action, 2021). In Orange County, California - like many places in the United States - climate change is a politically charged and controversial topic. When 20 states adopted the well-regarded Next Generation Science Standards (NGSS) in 2014, it was hoped that schools across the country would improve climate change education. However, we found that adopting new science standards does not necessarily mean that teaching and learning about
\end{abstract}

\section{J. Cunnion}

Harvard Graduate School of Education, 3270 Washington St, Apt 2, Boston, MA 02130, USA

F. Hua

Ying Zhi Jie Foreign Language Institute, Foshan Courtyard, Building 6, Room 1201. Foshan City, Guangdong 528300, China

e-mail: feifeihua@eagleonline.com.cn

M. McNicholl

Harvard Graduate School of Education, P.O. Box, 178642, Arlington, VA 2216, USA

S. Ospina ( $\square)$

Misk Schools I Harvard Graduate School of Education, 190 Mineola Boulevard, Apt 1L., Mineola, NY 11501, USA 
climate change has improved in general, and this is made more complex by the fact that each state determines its own education system, and little can be mandated at a national level. Many factors contribute to inadequate student learning about the causes, impact, and especially the strategies to mitigate climate change among Orange County middle school students. We aim for education leaders to understand these best practices and encourage them to apply these to their contexts. We offer a curriculum based on best practices, one that is peer-led and garners hope. We wish for students to see themselves as agents of change and leaders of the not-so-distant tomorrow who become inspired to mitigate, adapt, and reverse climate change.

\subsection{Introduction}

Our chapter focuses on creating a peer-led, action-based climate change curriculum in Orange County, California. Despite our focus on a specific context, we hope that leaders at all levels can distill the best practices we have found, apply them to their own communities, and urge members of the education community to implement curricula and other practices to best meet the needs of this most pressing issue. We will first discuss the current state of climate change and of climate change education in the context of Orange County, California. Secondly, we will discuss several factors contributing to the problem of ineffective student learning about the causes, impact, and strategies to mitigate climate change. Thirdly, we will discuss the literature review on some of the best practices to teach climate change. Lastly, we will offer a solution to the problem by providing a climate change curriculum that encourages hope among learners. Thus, students will see themselves as agents of change and leaders of the not-so-distant tomorrow who are inspired to mitigate, adapt, and reverse climate change.

\subsection{Analysis of the Problem}

Before describing the current state of climate change education, it is important to see the urgency behind climate change itself. $\mathrm{CO}_{2}$ emissions are the highest they have been in over 800,000 years, and the Arctic Ocean is expected to be ice-free by the middle of this century (Climate Change Evidence: How Do We Know?, 2021). Today's children are seeing and experiencing the impacts: California, for example, is seeing increases in asthma, more severe droughts, increased forest fires, and rising sea levels (Ehlers, 2020; Kloog et al., 2013; Orange County Water District, 2020). Time is not on our side: climate change scientists say we have eleven years left to avoid disaster (Wagner \& Samaras, 2019). Our world's youth are the primary stakeholders in this issue, as they will shoulder the burden of climate change's effects. Still, we know that secondary stakeholders such as parents, teachers, and policymakers will 
need to be on board to implement climate change education, therein presenting an additional challenge.

In thinking about the problem as a deficit, too little effective student learning is taking place about the causes, impact, and especially the strategies to mitigate climate change among Orange County middle school students. Several factors contributing to this problem is (1) poorly trained teachers or educators averse to teaching the controversial topic, (2) parental opposition, (3) politics, (4) the lack of quality teaching resources on climate change that promote action, and (5) no state requirement that each California public school student learns climate change to graduate. In fact, while a sound, basic understanding of the science of climate change is a foundation, a stronger emphasis on civic responsibility is key to successfully learning about-and acting on-climate change.

According to one framework developed by Hoffman, four sources of distrust explain why climate change is a polarizing subject in the United States. This can shed light on the beliefs education can reinforce and the implications we want to avoid (Hoffman, 2015).

The first source of distrust is that of the messenger. There is a commonly held belief that university professors and other academics, most of whom lean left in their politics, are guided by their political persuasions. The climate change debate is rife with character assaults of politicians and celebrities and with that, we urge that educators using our curriculum take note to avoid naming high-profile celebrities or politicians in their instruction.

The second source of distrust is related to the process that produced that message. There exists an idea that scientists are not to be trusted, that the merit of their research is based on its conformity to preconceived democratic ideologies (Hoffman, 2015). Our curriculum utilizes other disciplines, namely mathematics and science, so that students can see and take part in the process themselves and make their own observations, as opposed to only reading other people's conclusions.

Third, many people distrust the message itself. This can be understood from a psychological perspective: for many, the predictions made by climate scientists feel too catastrophic to be true. Some of this is tied to religion: for some, to believe that the future of the world lies in the hands of mankind challenges the notion of God. Conservative talk show host Rush Limbaugh, for example, once argued that you could not believe in anthropogenic climate change while believing in God (Hoffman, 2015). Religion is largely to be kept out of public schools due to U.S. law, but we do allow for students to voice doubts and questions and reframe the narrative so that students can see a responsibility to protect the earth as aligned with, not in opposition to, their faith.

Lastly, the fourth source of distrust is that of the solutions implied from the message. Many proposals made by environmentalists involve dismantling or kneecapping all nonrenewable energy industries, which stirs fears of economic recessions (Hoffman, 2015). By revealing a world of possible solutions, our hope is that students see the plethora of tools that already lay at our disposal and that there are still many to be designed. 


\subsection{Current State of Climate Change Education in the U.S. At the Middle School Level}

The cultural taboo of climate change has its implications for education. In January 2020, California Assemblywoman Luz Rivas introduced a bill to mandate the study of climate change, but ironically, the California wildfires and COVID-19 tabled discussion of the bill in the California Assembly and it expired (Leal, 2019). In response to Ms. Rivas' bill, the Chicago think-tank, The Heartland Institute, advised its readers:

"Climate alarm is being pushed in many state legislatures, where legislators are attempting to force a politicized ideology onto students trapped in government schools," Jarratt said. "Teachers should not be forced to teach a politicized, ideological view of climate change...The best way to prevent politics from taking over the classroom is to grant parents the power to remove their children from schools that teach in politically biased ways". (Arz, 2020)

An April 2019 NPR/Ipsos poll revealed 80\% of American parents and 86\% of teachers want their students to learn about climate change. Nevertheless, the average U.S. teacher spends just two hours per year on topics related to climate change. Furthermore, almost half of U.S. teachers do not teach it at all. According to a 2016 Science research article, most U.S. teachers are poorly informed about climate change and lack formal education on the subject - this can be attributed to generational gaps, as many teachers may have completed their training programs before climate change was an issue (Worland, 2016). Add to this that many history and science textbooks skirt the issue to avoid the controversial subject, favoring reassurances of progress over asking critical questions (Loewen, 2007). Hence, climate change education becomes treacherous ground for teachers. Without adequate and accessible resources, "a skilled teacher who wants to address climate change can do so, but an inexperienced teacher or one confronting climate denial will have a hard time" knowing how to address the topic (NSCE, 2020).

Educators are caught between the urgency of teaching climate change to this next generation who will bear the brunt of managing it, and the potential political fallout from teaching a controversial topic (Worland, 2016). The National Center for Science Education (NCSE) reports $40 \%$ of U.S. middle and high school teachers teach climate change as a matter of opinion, creating confusion in their students in their 2016 report, Mixed Messages: How Climate Change Is Taught in America's Public Schools. In the United States, law forbids the mandate of any curriculum on the federal or even state level-curricula are only adopted by local districts. Adding to the variability between states and districts is that of individual classrooms: How teachers unpack the standards and translate those to learning objectives can vary from classroom to classroom, and school to school within the same district, depending on how schools go about unpacking state standards into the curriculum taught. If a state's board of education required a specific number of credit hours of climate change education for teacher preparation and certification, this would improve teacher capacity, education materials, and student understanding of the issue. 
While adults argue, students sense the urgency about what they don't know: as middle-schooler Tom Walfield of Danvers, Massachusetts, states, "I will be 39 in the year $2040 \ldots$ and to put it plainly, I am terrified of the direction we are heading in. The fact that we could see a global crisis in 2040 over climate change is horrifying. I don't think I am as scared with climate change, as I am with how little we are actually doing to prevent it," (The Learning Network, 2018). A curriculum designed to empower students can then develop their capacity to influence peers and family members.

In fact, teaching middle-school children about climate change may be one of the most important things we can do to save the planet (Christensen, 2019). Developmentally, middle school students can grasp complex ideas while remaining open-minded. They can also influence their parents' perspectives on climate change. Interestingly, researchers found that middle-school daughters held the greatest sway in changing opinion of the most resistant group of all: middle-class males (Christensen, 2019). When climate change lessons are based around two elements-(1) encouraging interaction with family and (2) understanding the impact of climate change in a broader sense- they exert the greatest impact in inspiring individuals to act (Lawson et al., 2019; Leiserowitz et al., 2019).

Peer-assisted learning (Lesson 6 of our unit) can be of great benefit to teaching climate change education, because it can help students feel more relaxed and comfortable during sessions (Glyn et al., 2006). This is very important when dealing with topics that might cause anxiety. Additionally, peer learners will find it useful learning from someone that brings a student-like approach, and who is close to their age (Glyn et al., 2006). Finally, student peers are often trusted messengers who know which pieces of information are especially relevant because of shared common experiences. This learning strategy builds community and develops relationships as part of the learning process, which can be viewed as an added benefit for climate resilience (Ocana \& Wolfson, 2020). As members of the same generation, mentors and mentees would develop a "we" mindset that fosters a sense of unity and common purpose.

Making the Grade? released in October 2020 by the National Center for Science Education and the Texas Freedom Network Education Foundation, ranked every U.S. state after an evaluation by three scientists on the quality of the state's climate change curriculum. The twenty states that adopted the Next Generation Science Standards (NGSS) received a $\mathrm{B}+$ and five states did even better, proving that it is even possible to improve upon the NGSS. The remaining states received grades $\mathrm{C}+\mathrm{to} \mathrm{F}$, including some of the most populous states: their state standards "promote the false narrative that the existence, cause, and seriousness of climate change are a matter of debate among climate scientists," while other states fail to mention the issue explicitly or at all, or address it vaguely (Making the Grade? 2020). The report recommends states' science standards uniformly reflect scientific consensus on climate change, require that every teacher discusses the subject with their students, and requires both preservice and in-service study for teachers so that they are informed of current research (Making the Grade? 2020).

Climate change curriculum, if present at all, is typically found in middle school standards-however, middle school educators worry about frightening young 
students when teaching it (Westervelt, 2017). Nevertheless, middle school is the best developmental level to reach students to explore climate change, as this is where they understand complex systems and how they and others can be affected (Westervelt, 2017). Giving students opportunities for change makes them less likely to feel overwhelmed or discouraged, but more apt to act and inspire their family members to act towards improving climate policy (Lawson et al., 2019; Monroe et al., 2017). Lin Anderson, Director of Teacher Support at the National Center for Science Education (NCSE) suggests adding a "solutions element" to every middle school lesson on climate change to mitigate anxiety and emphasize action:

Studies are showing climate anxiety is very real for middle and high schooler students, but especially in middle school. I try to leave every lesson I do with an element of hope so that students realize there are technologies and ways to combat climate change while they learn about what is currently going wrong at the same time... the most important thing is to try to give them examples of ways we are winning already. (McNicholl, 2020)

The introduction of the Next Generation Standards (NGSS) has been a gateway to introduce climate change education into the curriculum in the middle and high school grades. To date, however, only 20 states have mandated the adoption of these standards, and 24 states have developed their own science standards using the recommendations of the NGSS standards (Next Generation Science Standards: For States, By States, 2013). Adopting the standards is a step forward, but more is required-for example, adequate teacher training and access to good quality resources. Furthermore, climate change education should not be the sole responsibility of science teachers. Other subject standards such as English, civics, and social studies, should include climate change, as it would maximize the opportunities for students to learn about climate change from various perspectives.

With this in mind, we can turn towards specific case studies of states with effective climate change curriculums. New Jersey was the first state in the country to mandate climate change be included in its standards - not only through NGSS, but also under other subjects like language arts and art (Official Site of The State of New Jersey). This reform since it is set to take effect in the 2021-2022 school year and is a promising step forward.

There are other states trying to include climate change education in their public schools. For example, Connecticut's House Bill 5215 sought to include climate change instruction in the state's public-school curriculum. As of 2020 , about " 18 measures to support climate change education in the public schools were active in the state houses of ten states" (Branch, 2020). California, for example, proposed that the adopted course for science include in courses material relating to the causes and effects of climate change. The bill, however, died in committee on June 19, 2020. The majority of the 18 measures failed to pass.

While politics, and other interests hinder the processes of climate change education making its way to every classroom in America, we hope to see the reform come from actions students take to make the case for climate change education. 


\subsection{Current State of Climate Change Education in California at the Middle School Level: What is Lacking in the Literature Review of Previous Climate Change Curriculum in California?}

In our creation of a climate change curriculum, one of the first questions we had to ask concerned contextual gaps of knowledge. For our context, we were working with the already existing NGSS standards, but recognize that education standardization is not utilized everywhere. Still, identifying these gaps can illuminate places for further focus depending on your region, and we encourage proponents of climate change education to do the same.

California education code 60,605.85 required the California State Board of education to adopt the Next Generation Science Standards for California Public Schools (NGSS for California Public Schools, K-12). The California Department of Education published a document where it listed a table as a suggested sequence for articulation across the middle school grades science curriculum. From looking at the table, it is evident that climate is explicitly taught in grade 6 . There is no expectation that it would be taught in other grade levels if following the publish articulation model (Table 7.1).

Table 7.1 Arrangement for articulation (California Department of Education)

\begin{tabular}{l|l|l|l|l|l}
\hline Grade & $\begin{array}{l}\text { Cross cutting } \\
\text { concepts }\end{array}$ & Life & $\begin{array}{l}\text { Earth and } \\
\text { space }\end{array}$ & Physical & Engineering \\
\hline Eighth & $\begin{array}{l}\text { Stability and } \\
\text { change; scale, } \\
\text { proportion and } \\
\text { quantity }\end{array}$ & $\begin{array}{l}\text { Natural } \\
\text { selection }\end{array}$ & $\begin{array}{l}\text { History of } \\
\text { the Earth } \\
\text { Space } \\
\text { systems }\end{array}$ & $\begin{array}{l}\text { Waves and } \\
\text { Electro-magnetic } \\
\text { radiation } \\
\text { Energy } \\
\text { Forces and } \\
\text { interactions }\end{array}$ & ETS \\
\hline Seventh & $\begin{array}{l}\text { Energy and } \\
\text { matter: flows, } \\
\text { cycles, and } \\
\text { conservation; } \\
\text { cause and effect }\end{array}$ & Ecosystems & $\begin{array}{l}\text { Natural } \\
\text { resources }\end{array}$ & $\begin{array}{l}\text { Structure and } \\
\text { property of matter }\end{array}$ & ETS \\
\hline Sixth & $\begin{array}{l}\text { Patterns; } \\
\text { structure and } \\
\text { function; } \\
\text { systems and } \\
\text { system models }\end{array}$ & $\begin{array}{l}\text { Cells and } \\
\text { Organisms }\end{array}$ & $\begin{array}{l}\text { Weather and } \\
\text { climate }\end{array}$ & Energy & ETS \\
\hline Fifth & $\begin{array}{l}\text { Energy and } \\
\text { matter: flows, } \\
\text { cycles and } \\
\text { conservation } \\
\text { Scale, proportion } \\
\text { and quantity }\end{array}$ & $\begin{array}{l}\text { Matter cycles } \\
\text { through living } \\
\text { and non-living } \\
\text { things }\end{array}$ & $\begin{array}{l}\text { Earth in } \\
\text { space, } \\
\text { interactions } \\
\text { of earth } \\
\text { systems }\end{array}$ & $\begin{array}{l}\text { Properties and } \\
\text { structure of matter }\end{array}$ & ETS \\
\hline
\end{tabular}


To further our analysis, we examined the available climate curriculum in California. Specifically, we reviewed three curriculum resources that are used across California:

1. The Education and Environment Initiative (EEI): upon registration and approval from the EEI, this provides teachers access to curricular material. The materials are for grades K-12, and deal with environmental topics in California. Within the units there is some information on how humans impact the environment, and some on the greenhouse gases. However, we did not find any unit that motivated students to take action to mitigate climate change.

2. Changing Planet is a curriculum developed by NBC Learn in conjunction with the National Earth Science Foundation and Windows to The Universe. The curriculum is based on a series of videos centered around "twelve key indicators of climate change, as well as lesson plans for teachers to use to explore the science behind these indicators with their students at the secondary level." (https://www.windows2universe.org/). The videos and the lesson plans are of high quality, but it's only recommended for high school students. This resource also does not call for action from the students.

3. Alliance for Climate Education: produces high-quality videos that educate youth on climate change and encourages students to act. However, it is not limited to a single context (state or school system) — thus limiting its relevance in this analysis.

Our curriculum builds on the limitations of the curriculums we explored. It is localized and action-driven and includes bite-sized science to build a conceptual understanding of the science behind climate change.

\subsubsection{Interviews with Orange County Science Teachers on Climate Change Education}

We interviewed current and former Orange County science teachers for their perspectives on the status of climate change curriculum in Orange County. Climate change education is spotty at best, varying from school to school, and dependent on the relative affluence of school districts' zip codes. Yet, it also varies even from teacher to teacher within a single science department. For example, one teacher in the Orange County system told us that although she wanted to teach the material, her conservative colleague was a climate change denier, and she was concerned about the resulting fallout (McNicholl, 2021). Professional development (PD) is carried out at the county level. The county dictates to teachers which PD workshops they need to attend and when. These workshops rarely involve specific areas of science content, however. Environmental problems might be used in these workshops, but only as examples of how to engage K-12 students and teach any science content more effectively (McNicholl, 2021). Optional PD offerings in climate change education do exist, but teachers self-select into those sessions-thus, the cycle continues. Finally, although 
there is a mechanism for writing district standards where teachers collaborate over the summer, it has not been done yet for climate change education.

California also faces a science teacher shortage. In 2017, half of incoming California science teachers entered classrooms without full credentials (Kohli, 2019). To address this gap, both the University of California and California State Universitythe institutions responsible for preparing over half of California's K-12 teacherslaunched the Climate Change Literacy Project, teaming teachers with scientists. This initiative should produce more informed teacher graduates entering California science departments, who could have a positive influence on their colleagues.

\subsection{Climate Change Lessons from Italy and Sweden}

In this section, we segue into taking note of bold initiatives in climate change education in Italy and Sweden, which can be used as comparative reference. Though these contexts are different from Orange County, they are some of the only examples of wide-scale climate change education. A year ago, Italy's pro-environment Prime Minister Fioramonti made history by announcing that in the 2020-21 academic year, Italian K-12 students would be required to learn about climate change, becoming the first country to ever require climate change in the national curriculum with the end goal of becoming "sustainable citizens." Italian students will spend at least $33 \mathrm{~h}$ per year studying climate change, with a transdisciplinary focus that emphasizes civics, math, physics, and geography classes alongside courses in science (Horowitz, 2019).

Although Sweden does not have the same mandate for explicitly teaching climate change as Italy, its 50-year history of teaching environmental education reflects Sweden's citizens' appreciation for nature (Cars \& West, 2014). Sweden's sustainability development education is noteworthy because it emphasizes outdoor education and social responsibility, in addition to science. Based on this, we can see that while science is an integral component to understanding climate change, it is not the only component. This is consistent with other research that shows that too much scientific complexity obscures foundational concepts and implies that only experts can address the issue (Rhodes \& Wang, 2021). This emphasis on building children's relationship with the natural world shows correlation with a will to preserve it. In effect, though Sweden does not have an enforceable mandate as Italy does, Sweden has been teaching climate change education in practice (Olander \& Olander, 2016).

We acknowledge that Italy and Sweden are homogenous countries, and that their education is mandated at the national level. In contrast, educational policy in the United States is determined by each of the individual 50 state boards of education. Nevertheless, we can transfer these salient ideas from Italy and Sweden to implement climate change education in every part of the U.S. education ecosystem and focus on the civic responsibility aspect of climate change education to motivate students to find creative solutions. 


\subsection{Best Practices and Rationale of Our Curriculum}

How climate change is taught will depend on the national and regional context and the grade level of the students. Since there are so few examples of wide-scale climate change education, there is little research on most effective practices (or, as mentioned earlier, what could even be defined as "effective"). These practices are distilled from the previously cited research on Italy and Sweden, and from a variety of climate change curricula that spoke to knowledge gaps and the political controversy. From what we explored, the most appropriate practices for our context will be to: 1. Make CCE personally relevant, 2. Include experiential learning and outdoor education, 3. Encourage the transfer of local knowledge to global awareness (i.e., going "glocal"), 4. Implement a transdisciplinary approach to CCE, 5. Teach systems thinking, 6 . Use a solution-oriented approach to CCE, 7. Implement peer-to-peer learning, and 8. Talk through the controversy of climate change.

One of the most effective themes we found is the need to make climate change education personally relevant to the student. Climate change researchers suggest students need to see climate change not as a hypothetical or nebulous threat, but something observable within their own communities (Monroe et al., 2017). Furthermore, there is also emphasis on engaging learners experientially through labs, field trips, and in-class debates (Monroe et al., 2017). Still, students need to explore beyond their local context. While local projects are certainly meaningful, this learning method has limitations, as project-based curricula often ignores how students can transfer what knowledge they gain outside of the given context (Rhodes \& Wang, 2021). The implications we see here would be for our curriculum to demonstrate the relationship between students' local communities and the rest of the natural world.

Regarding making climate change education hands-on and engaging, while we have limited power in our curriculum to execute field trips, we can provide information resources and recommend Orange County schools take this into consideration. Given the region's proximity to many natural landscapes and environmental organizations, students could benefit from being able to interact with scientists. Interaction with scientists (and the tools they use) has shown to be effective in building students' interest in climate change (Monroe et al., 2017).

A transdisciplinary approach - or integrating multiple disciplines to teach an idea-is particularly useful in teaching climate change and sustainable development. To quote research offered by Lekies and Moore (2020), "Transdisciplinary methods draw from multiple and often unrelated disciplines, integrate and synthesize information, allow for new collaborations, foster mutual understanding, engage nonacademic stakeholders, and generate and apply new knowledge" (Lekies and Moore, 2020). Incorporating tools learned in social sciences, mathematics, and biology makes the content more relevant and relatable mimicking the same intricacies and connections made in real life. According to Yu and Chiang (2017), transdisciplinary approaches are beneficial for students in that they result in "better performance in practical modules" and they address "the real interest of the students." Additionally, creating a climate change curriculum with multiple lenses "provides the students 
with a range of different perspectives for addressing climate change, perspectives they can draw on to formulate changes in status quo systems, based on the use of these perspectives" (Beach et al., 2017). When students hear, for example, how climate change impacts individual people, students further develop their connection to the environment by building empathy (Wallace, 2019). We sought to develop a transdisciplinary curriculum that explored the science of climate change, while also teaching ethical decision making, civics, and global citizenship. An example in our curriculum is our transdisciplinary modules targeting climatic risks in Orange County. For instance, when we create a module on air quality in Orange County, we would not only emphasize the scientific indicators that determine the quality, but also the human factors that affect air quality, such as the impact poor air quality has on various human populations, and actions we can take to solve such problems.

Global and local action is necessary if we are to mitigate, adapt to, and ultimately reverse climate change. Becker (2017) argues education at the local level should always be approached with respect to the local/regional situation, and possibly also in consideration of the global aspects, expressed in the newly created word 'glocal.' In our proposed curriculum, we include an action component for the summative assessment for the module. The action will be pegged to a local climatic risk present in Orange County.

The most recent adoption of NGSS standards in California requires the teaching of systems and systems models (Next Generation Science Standards: For States, By States, 2013). One high school standard related to environment and human actions states: "Use a computational representation to illustrate the relationships among Earth systems and how those relationships are being modified due to human activity" (Next Generation Science Standards: For States, By States, 2013). Although the standards expose students to systems thinking, they do not explore systems in a broader sensesuch as how, for example, air pollution can affect the economic system of a country, or the healthcare system because of chronic disease developed from poor air quality. This is an important consideration for our curriculum, as we embed in our modules system and system thinking, by using Harvard's Project Zero's Agency by Design tools to introduce systems thinking.

Another component included in our curriculum to fit our context is cooperative and peer-assisted learning. The model that our client, Best Delegate, employs is one in which high school students teach and coach middle school students. We reviewed literature for examples of peer-learning in climate change education and sustainable development, but there was little available. We did a broader search to determine a peer-assisted learning model that could be transposed onto our curriculum. Peerassisted learning is defined as a "situation in which people from similar social groupings who are not professional teachers help each other to learn and learn themselves by teaching" (Glyn et al., 2006). Glyn et al. (2006) noted the peer learner and the peer teachers "described feeling more relaxed and comfortable during the session," which can be particularly useful for us, as climate change can be a difficult topic to discuss. After all, climate change is highly politically- and religiously- charged in the context of the U.S. educational system, and one reason teachers shy away from teaching it at all. Another benefit was peer learners emphasized "they felt the peer 
teachers would bring a unique and very useful perspective to the session due to their immediacy with the material and their student-like approach" (Glyn et al., 2006).

Cooperative learning is essential to developing twenty-first century skills and is ideal for learning about the topic of climate change education. Cooperative learning allows students to "work together to accomplish shared goals, and there is a mutual responsibility to work for one's own success" (Johnson \& Johnson, 2012). Of the four types of cooperative learning Johnson and Johnson describe, including formal and informal cooperative learning, cooperative base groups (providing long-term academic support), and constructive controversy (cooperation involving intellectual conflicts). The latter is most applicable in helping students understand their own positions on climate change. Constructive controversy can be defined when "one person's ideas, opinions, information, theories, or conclusions are incompatible with those of another, and the two seek to reach an agreement" (Johnson \& Johnson, 2012). This definition is useful given the research that shows the need for teachers to talk through the controversy of climate change (Monroe et al., 2017). Thus, by introducing and embracing conflict, students learn to actively listen to multiple perspectives, find common ground, and find creative solutions. Ideally, our curriculum would include a simulation on a climate change topic that would involve students breaking into groups defined by a stakeholder-farmers, automobile workers, residents of coastal areas, etc. - and students would need to define their positions on the conflict, then actively work with other groups to discuss their positions, and finally cooperatively arrive at a mutually acceptable outcome.

In teaching through controversial subjects, it is essential for the curriculum to create space for students to decode their own biases and determine the credibility of information (Rhodes \& Wang, 2021). Teaching with a constructivist approach rather than a transmission-based approach would allow students to interpret information independently - in essence, discover for themselves - and talk through what skepticism or misconceptions they may have. Such a design would encourage skills in inquiry and analysis (Rhodes \& Wang, 2021).

An important limitation we must consider when applying the best practices we have discussed in our context is that we create a curriculum taught by non-teachers (high school students); therefore, we need to make sure it is scripted and scaffolded as much as possible. On the other hand, the advantage of having the heavily scripted and scaffolded curriculum is that other non-teacher users can use the material to teach, and teachers with little training who are new to the topic can also use it as a guide.

In addition to incorporating the best practices discussed above, we have broken down our curriculum unit into four modules, each containing several lessons. As noted by The Environmental and Energy Study Institute (2019), the four modules are based on four scientific ideas about climate change that scientists agree on: "It's real, It's us, It's bad, There's hope." All our lessons are aligned to the NGSS Standards, Common Core standards, the UN Sustainable Development Goals (where applicable) and to our client's desired goals of student skill set achievement.

It's real: Our first module is dedicated to establishing a safe space for students to engage in constructive controversy. We did so by creating a lesson about setting up 
norms of engagement that students will adhere to during the unit. We then proceed by introducing a lesson that explains what science is, how scientific inquiry is done, and why we should believe scientists. The lesson gives students a toolkit, consisting of methods to judge whether something is based in science or not and ways to critically engage with information they receive. We included the toolkit because, as noted by Rhodes and Wang (2021), "It is essential for the curriculum to create space for students to decode their own biases and determine the credibility of information."

In the "It's real" module, we present students with local and global images of climatic risks, and some solutions developed to tackle them. The module introduces local evidence of climate change that makes the situation more personal, while also presenting more global evidence. The images we presented were carefully curated, as recommended by the Climate Visual's "seven core principles for effective visual communication" (n.d.). These principles are as follows: 1. Images show real people, 2. Tell new stories; 3. Show climate change causes at a scale (systems), 4. Show emotionally powerful impacts, 5 . Understand your audience (we chose images that were appropriate for young students), 6. Show local (but serious) impacts, 6. Be careful with protest imagery (Climate Visuals n.d.). Students are expected to engage with the images following one of Harvard's Project Zero Thinking Routines: "See, Think, Wonder" (See, Think, Wonder n.d.).

The module culminates by introducing the students to the summative project and introducing some of the science by looking at temperature change. The summative project asks students to pitch a solution to a climatic risk for Orange County. The pitch will be delivered in a Pecha Kucha presentation format, which allows students to tell their story in twenty images, with twenty seconds for each image. The series of pitches would be presented in front of an audience and decided by the students but would ideally include members outside of the classroom. This module teaches students the difference between climate and weather and builds an understanding of how temperature has increased over an extended period even as cold weather events continue to occur. This naturally leads us to ask the reasons behind these changes, which leads to the next idea: It's us.

It's us: This module makes the relationship between climate change and human activity personally relevant to the students. It begins by having students calculate their family's carbon footprint, by examining and listing their everyday activities and those of their family members. This is designed to encourage productive and educational discussion at home. Given that our surveys identified a disproportionate number of students whose parents are climate change contrarians, this module could influence their families' perspectives through discussion. Moving from the family level to the global level, the final lesson in the "It's us" module exemplifies human impact at a systems level-which, as we noted in our literature review, is not necessarily covered in the NGSS standards. This lesson aims to connect personal actions to widespread impacts so that students see how the total sum of human activity comes with a hefty $\mathrm{CO}_{2}$ price tag, connecting to the next module's theme.

It's bad: In this module, students explore the deleterious impacts of climate change. We start again from a local context, by having students learn about the wildfires that have ravaged California and their causes. Following this series, students 
explore how climate change affects communities across the world, and how some communities are affected more than others. Students build understanding that climate change does not just mean a change in temperature, but also an increase in extreme weather events, health problems, and disruptions in food access. It is here we want students to see that while they and many others may be insulated from many (though not all) of the effects of climate change, others are not so fortunate. These multiple perspectives aid students in developing "empathy, triggered by making a connection to the environment" (Wallace, 2019).

There's hope: Our culminating module, designed to be the final of the four, is intended to end with a hopeful, inspiring, and action-oriented message. The first lesson in this module introduces students to some of the technology developed to mitigate climate change, as well as the barriers to committing to such technologies. The second lesson then explores legislation in different places that have been enacted in response to climate change. This lesson allows students to see how policy influences our day-to-day lives and demonstrates how people can influence and hinder the development of legislation. Students are also given space to discuss why someone may refute climate science or oppose different solutions.

The last two lessons in the module are dedicated to students applying and demonstrating all they have learned throughout the curriculum. The penultimate lesson has students presenting their climatic solution via Pecha Kucha pitches to an audience of their choice. We leave room for flexibility at this point of the curriculum implementation but encourage students to consider presenting to people outside of their school community and/or via social media or other online platforms.

The last lesson is a simulation of a climate change summit. Students will take the roles of various stakeholders and solve a climate issue. In this simulation, students will practice skills of persuasion, negotiation, and data analysis as they discuss priorities and finalize a decision on a given topic - in this case, a question of dam renovation. By immersing themselves in a real scenario about water resource planning, students engage in meaningful conversations, and understand that differences in goals create conflict-after all, there are few climate solutions that are obvious and universally supported.

\subsection{Theory of Change}

While carrying out our literature review, we found that climate change education (CCE) and sustainability development education both teach the impact of human activity on the environment. According to UNESCO (2021), the purpose of climate change education in the context of sustainability development is "To help audiences understand, address, mitigate, adapt to, and reverse the impacts of climate change, we need to put our world on a more sustainable path of development and build a new generation of climate change-aware citizens."

Translating this global goal to our context, Orange County, the long-term goal of our project became to reduce carbon emissions in Orange County by at least ten 
percent in ten years. This objective carries the assumption that population growth in the area remains stable in that time. If schools had an action-oriented and accessible curriculum, one which fostered a sense of common purpose with peer-to-peer learning, then we would see students adopt more environmentally conscious behaviors, such as choosing biking over driving. These behaviors could then influence behaviors in the wider community. More environmentally conscious behaviors would then result in reduction of carbon emissions and other greenhouse gas emissions. To measure how many students changed their behaviors, we would use pre- and postcurriculum surveys to probe the manner and frequency of various student-performed activities. For students to demonstrate the desired change in behaviors, we would need to ensure that a certain number of students completed the curriculum, and this could be evidenced by the completion of work throughout the curriculum and the number of Pecha Kucha presentations that occurred at each site.

It is a major assumption that school leaders will find, download, and implement the curriculum. Necessary activities to achieve this desired output include publicizing the curriculum via Best Delegate's website, highlighting its strengths, and creating an implementation guide for teachers, peer mentors, and peer mentees, such that lessons are clear, focused, and balance structure with flexibility (Table 7.2).

We recognize that our theory holds several key assumptions, and that schools are open systems generally. We have aimed to utilize tools that best inform us of the quality of our design and allow us to improve on our practices.

\subsection{Setting the Stage for Change (Five Perspectives)}

We used Reimers' five perspectives to analyze the assumptions underlying our approach. We felt this step was crucial to make sure that our activities were diverse, and that we incorporated at least some of the perspectives' elements within our plan for change (Reimers, 2020).

Cultural: An assumption underlying the cultural lens holds that many of the students come from families whose parents might be climate change contrarians in Orange County. For example, one reason for their conflict with the idea of climate change might stem from religious beliefs that they feel contradict science. Hence, our curriculum provides the students with the knowledge of what science is and what it can and cannot answer, giving them critical thinking tools to judge whether an idea is based in science or not. Even if our assumption is wrong, having this activity will still be beneficial for the students, and the change we seek to happen should lead to some form of cultural change.

Psychological: We are assuming that we can change students' behaviors, and their behavior changes can influence those of their parents and other members of their community - this is challenging, but possible. To make changing behavior easier, neuroscience research advises to "include a reward with personal sources of value by linking the new behavior with core values and beliefs that are central to the person's identity" (Berkman et al., 2017). Meaning, if we give students tools that 
Table 7.2 Logical framework of the curriculum

\begin{tabular}{|c|c|c|c|c|}
\hline & Project description & $\begin{array}{l}\text { Objectively } \\
\text { verifiable indicators } \\
\text { of achievement }\end{array}$ & $\begin{array}{l}\text { Sources and means } \\
\text { of verification }\end{array}$ & Assumption/risk \\
\hline Goal & $\begin{array}{l}\text { Adoption of more } \\
\text { eco-conscious } \\
\text { behaviors and } \\
\text { greater } \\
\text { environmental } \\
\text { advocacy }\end{array}$ & $\begin{array}{l}\text { Percent reduction in } \\
\mathrm{CO}_{2} \text { emissions \# of } \\
\text { people who name } \\
\text { the environment as } \\
\text { their biggest } \\
\text { political issue }\end{array}$ & $\begin{array}{l}\text { Comparison of data } \\
\text { publicly available }\end{array}$ & $\begin{array}{l}\text { Population growth } \\
\text { remains stable in } \\
\text { Orange County }\end{array}$ \\
\hline Outcome & $\begin{array}{l}80 \% \text { of students } \\
\text { demonstrate } \\
\text { change in } \\
\text { knowledge and } \\
\text { behaviors within } \\
\text { the year of taking } \\
\text { course }\end{array}$ & $\begin{array}{l}\text { Students can } \\
\text { identify climatic } \\
\text { risks, ways to adapt } \\
\text { and mitigate climate } \\
\text { change, and display } \\
\text { climate friendly } \\
\text { behaviors }\end{array}$ & $\begin{array}{l}\text { Pre- and post-unit } \\
\text { surveys }\end{array}$ & $\begin{array}{l}\text { Survey responses } \\
\text { are accurate }\end{array}$ \\
\hline \multirow[t]{2}{*}{ Output } & \multirow[t]{2}{*}{$\begin{array}{l}\sim 1,000 \text { students } \\
\text { complete the } \\
\text { curriculum each } \\
\text { year }\end{array}$} & \multirow[t]{2}{*}{$\begin{array}{l}\text { Number of students } \\
\text { completing the } \\
\text { curriculum }\end{array}$} & $\begin{array}{l}\text { Journals/portfolios } \\
\text { documenting their } \\
\text { work through the } \\
\text { modules }\end{array}$ & \multirow[t]{2}{*}{$\begin{array}{l}\text { Students complete } \\
\text { all module } \\
\text { activities and } \\
\text { learning journals } \\
\text { within a semester }\end{array}$} \\
\hline & & & $\begin{array}{l}\text { Number of Pecha } \\
\text { Kucha } \\
\text { presentations } \\
\text { demonstrating their } \\
\text { climatic risk } \\
\text { solutions }\end{array}$ & \\
\hline \multirow[t]{3}{*}{ Activities } & $\begin{array}{l}\text { Make the } \\
\text { curriculum widely } \\
\text { accessible, make it } \\
\text { visible by } \\
\text { marketing it on the } \\
\text { Best Delegate } \\
\text { website and social } \\
\text { media }\end{array}$ & \multirow[t]{3}{*}{$\begin{array}{l}\text { The curriculum, the } \\
\text { implementation } \\
\text { plan and the guide } \\
\text { for adaptation to } \\
\text { different contexts } \\
\text { are widely } \\
\text { accessible and easy } \\
\text { to find }\end{array}$} & \multirow[t]{3}{*}{$\begin{array}{l}\text { Number of } \\
\text { downloads off the } \\
\text { Best delegate } \\
\text { website }\end{array}$} & \multirow[t]{3}{*}{$\begin{array}{l}\text { Teachers/students } \\
\text { will download } \\
\text { curriculum and } \\
\text { teach it in its } \\
\text { entirety }\end{array}$} \\
\hline & $\begin{array}{l}\text { Provide } \\
\text { implementation } \\
\text { guide }\end{array}$ & & & \\
\hline & $\begin{array}{l}\text { A guide for } \\
\text { adaptation to } \\
\text { different contexts } \\
\text { to maximize } \\
\text { impact }\end{array}$ & & & \\
\hline
\end{tabular}


develop empathy, interpersonal, and intrapersonal skills, we will be helping them look at their values and grow in their thinking. The reward can be as simple as either feeling better about making a change that benefits others or being extrinsically motivated by successfully presenting solutions and getting recognition for it.

We also considered the psychology of learning, including Bloom's Taxonomy, to ensure that the students were not merely memorizing the material. In different parts of the curriculum, we asked the students to apply, analyze, evaluate and create, all corresponding to an increasing level of complexity, culminating in having students create a solution to one of the climatic risks identified in their context. Lastly, there is the psychology of emotion. As noted, this topic can stir anxiety and challenge the idea that the world is naturally orderly and stable. We respond to this by incorporating solutions and messages of hope.

Professional: One reason teachers shy away from teaching climate change education is that they have not received adequate training, or that with the multitude of resources available it is hard to know where to begin. We made sure our curriculum was scaffolded and scripted in some cases so that peer mentors could use it easily. The curriculum could be used by a beginner teacher with no training on climate change and could also be easily modified by more experienced teachers. Although we wished to make a coherent, logical and sequenced curriculum, we designed lessons and modules that could also stand on their own. We have also thought about how to help teachers and peer mentors in other contexts modify the curriculum, which we will review in the section about implementation.

Institutional: From our conversations with our client and from looking at the NGSS science standards, we know that climate change has been taught in Orange County. As mentioned earlier in the paper, California received a B+ grade in a report from the National Center for Science Education and Texas Freedom Network Education Fund (Making the grade? 2020). One reason is that the language in the standards refer to climate change as something humans are influencing, rather than causing. We assume that within our client's network, there are a mix of schools with a varying degree of climate change education. Some schools might have a wellestablished curriculum that addresses climate change, and some might be without such a curriculum. Though we might not enact institutional change through this project alone, we hope that the students and teachers who use our curriculum will be empowered to take action that influences policy and technology.

Political: In the US, climate change is a highly politicized topic, which has led many stakeholders with competing agendas to sensationalize the "debate" of climate change. This debate could hinder some legislators' efforts in proposing laws that could positively affect the environment. We stay clear of mentioning specific political parties or candidates and their agendas for addressing climate change, as this might shut down students with opposing political views. However, it would be irresponsible for us to not acknowledge the controversy of the topic. We build in space for discussion that allows for students to understand competing goals while maintaining that certain facts are undebatable. We also hope that the students become empowered to participate in bottom-up reform by reaching out to policymakers who could use their power to make changes regionally, nationally and even globally. 


\subsection{Impact Evaluation}

As the climate change curriculum must be adapted to different contexts before implementation, formative evaluation can be a very useful tool in making course materials relevant to students. Formative evaluation can help student leaders and teachers understand what class activities and materials would best engage the target students and reach their instructional goals. Student leaders and teachers can test teach a sample lesson or conduct interviews with target students who resemble attitudinal and behavioral research methods. In the implementation guide we provide with the curriculum; we will include a list of indicators that demonstrate how well the adaptation is meeting the instructional goals and engaging the students. In addition, it is always helpful to seek feedback from local teachers, student leaders and activists, and experts or practitioners in climate change as the curriculum is being adapted.

For the summative or impact evaluation, we will mainly be measuring the indicators set out in our logical framework. Table 7.3 summarizes the data collection plan.

Curriculum adapted to different contexts can set out indicators based on the local context. Besides measuring the indicators, it is also important to understand the impact the curriculum will have beyond the target students. We can employ the Creating Communities of Innovation Spheres of Influence tool developed by Project Zero at Harvard. The tool "helps to look beyond our immediate environment and consider broader impacts our innovation project may have on various stakeholder groups" (Sphere of Influence, 2019). Using this tool, we constructed a sphere of influence that includes target students, the school adopting the curriculum, the local community and students and teachers worldwide.

As the tool suggests, it is important for designers and implementers to reflect on the impact the project has had on each sphere (Sphere of Influence, 2019). Although the target students will be the direct beneficiaries of our curriculum, their learning outcomes and behavioral changes will very likely influence their peers in the same school. We also encourage students to post their solution-oriented presentation, the Pecha Kucha, on a designated website so that social entrepreneurs, policy makers, or other climate change activists in the local community might be inspired to act. Through the Model UN simulation where students debate on the issue as different stakeholders, we hope to bring together students and teachers worldwide who are using our curriculum and those who are passionate about climate change. Reflecting on the sphere of influence will allow us to explore new potential channels through which we can disseminate our curriculum and best practices. 


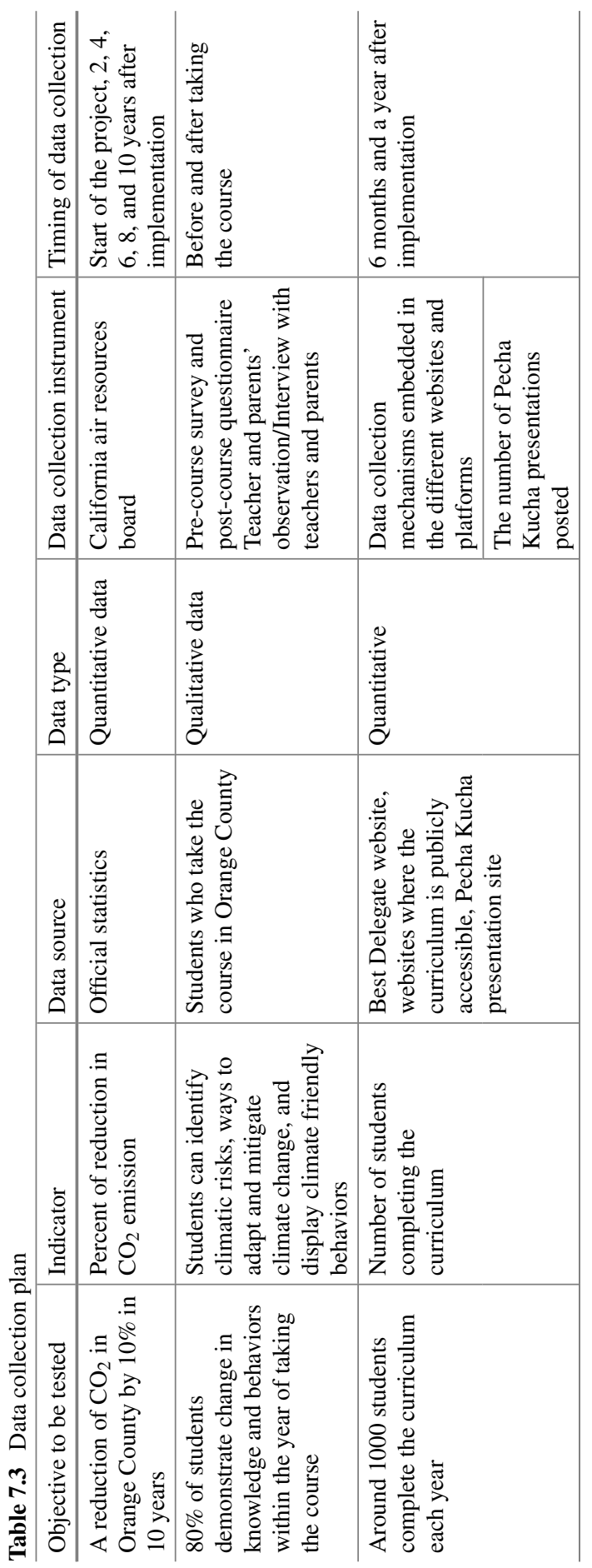




\subsection{Conclusion}

Teaching climate change is politically charged and controversial. In the United States, the task is made more challenging by the absence of curricular standards and mandates, unprepared teachers and parents, and high-quality learning materials that are accessible and relevant. Considering this, we propose an action-based, peer-assisted climate change curriculum, which empowers students to be agents and leaders in mitigating, adapting and reversing climate change. The design of learning activities is informed by best practices worldwide, particularly from Italy and Sweden. We are aware of the variety of climatic risks, as well as the cultural and political barriers to teaching climate change across contexts. Therefore, we highly encourage student leaders and teachers worldwide to make use of our implementation guide in adapting the teaching and learning materials to a local context. We hope our work creates a platform where educators, students and climate change advocates can exchange effective practices in teaching and learning about climate change. We are committed to working with different stakeholders to improve and update the curriculum - the future of our planet relies on a generation of informed, inspired, and proactive students.

\section{References}

About. Climate Visuals. (n.d.) https://climatevisuals.org/about.

Arz, K. (2020, March 20). California considers imposing climate change education. Retrieved December 06, 2020, from https://www.heartland.org/news-opinion/news/california-considersimposing-climate-change-education.

Beach, R., Share, J., \& Webb, A. (2017). Interdisciplinary teaching about climate change. Teaching Climate Change to Adolescents, 116-130. https://doi.org/10.4324/9781315276304-8.

Becker, G. (2017). Climate change education for sustainable development in Urban educational landscapes and learning cities. Experiences perspectives from Osnabrück. World Sustainability Series Lifelong Learning and Education in Healthy and Sustainable Cities, 439-469. https://doi. org/10.1007/978-3-319-69474-0_26.

Berkman, E. T., Livingston, J. L., \& Kahn, L. E. (2017). Finding the "self" in self-regulation: The identity-value model. Psychological Inquiry, 28(2-3), 77-98.

Branch, G. (2020, April 15). The year in pro-climate-change-education legislation: National Center for Science Education. The year in pro-climate-change-education legislation. National Center for Science Education. Retrieved February 7, 2021, from https://ncse.ngo/year-pro-climate-changeeducation-legislation

Cars, M., \& West, E. E. (2014). Education for sustainable society: attainments and good practices in Sweden during the United Nations Decade for Education for Sustainable Development (UNDESD). Environment, Development and Sustainability, 17(1), 1-21. https://doi.org/10.1007/ s10668-014-9537-6

Christensen, J. (2019, May 10). Middle schoolers may be the secret weapon in fight against climate change. Retrieved December 4, 2020, from https://www.cnn.com/2019/05/10/health/climate-cha nge-middle-schoolers-study/index.html.

Climate change evidence: How Do We Know? (2021, January 22). Retrieved January 24, 2021, from https://climate.nasa.gov/evidence/. 
Education for climate action. UNESCO. (2021, July 13). Retrieved October 19, 2021, from https:// en.unesco.org/themes/education-sustainable-development/cce.

Elliot, T., Berkman Jordan, L., Livingston Lauren, E., Kahn (2017). Finding the "self" in selfregulation: The identity- value model. Psychological Inquiry, 28(2-3), 77-98. https://doi.org/10. 1080/1047840X.2017.1323463

Environmental and Energy Study Institute (EESI). (2019). Environmental and energy study institute: Ideas. Insights. Sustainable solutions. EESI. https://www.eesi.org/.

Ehlers, R. (2020, August 10). What threat does sea-level rise pose to California? (Rep.) Retrieved September 23, 2020, from Legislative Analyst's Office website: https://lao.ca.gov/reports/2020/ 4261/sea-level-rise-081020.pdf.

Glyn, L. G., MacFarlane, A., Kelly, M., Cantillon, P., \& Murphy, A. W. (2006). Helping each other to learn-A process evaluation of peer assisted learning. BMC Medical Education, 6(18). https:// doi.org/10.1186/1472-6920-6-18.

Hoffman, A. J. (2015). How culture shapes the climate change debate. Stanford University Press.

Horowitz, J. (2019, November 5). Italy's students will get a lesson in climate change. Many lessons, in fact. The New York Times. https://www.nytimes.com/2019/11/05/world/europe/italy-schoolsclimate-change.html.

Interview with Gloria Harwood [Telephone Interview by M. McNicholl]. (2021, January 27).

Interview with David Marrett, Ph.D. [E-mail interview by M. McNicholl]. (2021, February 1).

Italy Mandates Climate Change Education for All Students. NYC Food Policy Center. (2019, December 1). https://www.nycfoodpolicy.org/italy-mandates-climate-changeeducation-for-allstudents.

Johnson, D. W., \& Johnson, R. T. (2012). Cooperative learning in 21st Century. [Aprendizaje cooperativo en el siglo XXI]. Anales De Psicología, 30(3). https://doi.org/10.6018/analesps.30. 3.201241 .

Kloog, I., Ridgway, B., Koutrakis, P., Coull, B. A., \&; Schwartz, J. D. (2013). Long- and short-term exposure to PM2.5 and mortality. Epidemiology, 24(4), 555-561. https://doi.org/10.1097/ede.0b0 13e318294beaa.

Kohli, S. (2019, December 31). Students want climate change lessons. Schools aren't ready. Retrieved February 08, 2021, from https://www.latimes.com/california/story/2019-12-23/stu dents-want-climate-change-lessons-schools-arent-ready.

Lawson, D., Stevenson, K., Peterson, M., Carrier, S., Strand, R., \& Seekamp, E. (2019, May 06). Children can foster climate change concern among their parents. Retrieved December 1, 2020, from https://www.nature.com/articles/s41558-019-0463-3.

Leal, F. (2019, October 11). Weekly roundup: Climate change awareness campaigns spread across schools, OC test scores steadily improve, and more. OCDE Newsroom. https://newsroom.ocde. us/weekly-roundup-climate-change-awareness-campaigns-spread-across-schools-oc-test-sch ools-steadily-improve-and-more/.

Lekies, K. S., \& Moore, R. H. (2020, August 4). Promoting transdisciplinary learning through a summer course on climate, water, and agriculture. ACSESS. https://acsess.onlinelibrary.wiley. com/doi/10.1002/nse2.20023.

Leiserowitz, A., Kotcher, J., Cutler, M., Rosenthal, S., Roser-Renouf, C., \& Maibach, E. (2019, January 05). Climate change in the American mind: March 2018. Retrieved December 1, 2020, from https://climatecommunication.yale.edu/publications/climate-change-americanmind-march-2018/.

Loewen, J. W. (2007). Lies my teacher told me: Everything your American history textbook got wrong. Simon \& Schuster.

Making the Grade? (2020, October). Retrieved December 06, 2020, from https://climategrades.org/.

McNicholl, M. (2020, September 30). The Status of Assembly Bill 1922. personal.

Monroe, M. C., Plate, R. R., Oxarart, A., Bowers, A., \& Chaves, W. A. (2017). Identifying effective climate change education strategies: A systematic review of the research. Environmental Education Research, 25(6), 791-812. https://doi.org/10.1080/13504622.2017.1360842. 
NGSS for California Public Schools, K-12. NGSS for California Public Schools, K-12-Science (CA Dept of Education). https://www.cde.ca.gov/pd/ca/sc/ngssstandards.asp.

NGSS Lead States. (2013). Next Generation Science Standards: For States, By States. https://www. nextgenscience.org/.

NSCE Referral for Climate Change Curriculum [E-mail to M. McNicholl]. (2020, December 9).

Ocana, M., \& Wolfson, I. (n.d.) (2020). Promoting peer-to-peer learning for climate adaptation (Rep.). Boston, MA: UMass Center for Agriculture, Food and the Environment.

Olander, M. H., \& Olander, C. (2016). Understandings of climate change articulated by Swedish secondary school students. Journal of Biological Education, 51(4), 349-357. https://doi.org/10. $1080 / 00219266.2016 .1233130$

Orange County Water District. (2020). Drought in California. https://www.ocwd.com/learning-cen ter/water-use-efficiency/drought/.

Reimers, F. (2020). Thinking multidimensionally about ambitious educational change. In AUDACIOUS EDUCATION PURPOSES how governments transform the goals of (pp. 1-44). In Reimers, F. (2020). Educating Students to Improve the World. Cham, Switzerland: Springer.

Rhodes, D., \& Wang, M. (2021). Learn to lead: Developing curricula that foster climate change leaders. D. In F. Reimers (Ed.), Education and climate change (pp. 45-83). Essay, Springer Open.

See, Think, Wonder. Project Zero. (n.d.). https://pz.harvard.edu/resources/see-think-wonder.

Spheres of Influence. Project Zero. (2019). https://pz.harvard.edu/resources/spheres-of-influence.

The Learning Network. (2018, October 11). What students are saying about: Climate change, Young Adult Novels and Snail Mail. Retrieved December 10, 2020, from https://www.nytimes. com/2018/10/11/learning/what-students-are-saying-about-climate-change-young-adult-novelsand-snail-mail.html.

Time. https://time.com/4214388/science-teachers-climate-change/.

Wagner, G., \& Samaras, C. (2019, September 19). Do We really have only 12 Years to avoid climate disaster? Retrieved December 11, 2020, from https://www.nytimes.com/2019/09/19/opinion/cli mate-change-12-years.html.

Wallace, H. D. (2019). Transdisciplinary learning in a kitchen garden: Connecting to nature and constructing a path to Eco literacy? International Research in Geographical and Environmental Education, 28(4), 309-323. https://doi.org/10.1080/10382046.2019.1646013

Westervelt, E. (2017, April 12). Educators on a hot topic: Global warming 101. MPR News. Retrieved January 3, 2022, from https://www.mprnews.org/story/2017/04/21/npr-educators-on-hot-topicglobal-warming

Worland, J. (2016, February 11). Why U.S. Science teachers struggle to teach climate change.

Yu, C.-Y., \& Chiang, Y.-C. (2017). Designing a climate-resilient environmental curriculum-A transdisciplinary challenge. Sustainability, 10(2), 77. https://doi.org/10.3390/su10010077.

Janna Cunnion has years of experience teaching in public and charter schools in several US states, as well as in four countries. She has an Ed.M. in Elementary Education from Boston University and an Ed.M. in International Education Policy from the Harvard Graduate School of Education. Her work focuses on closing gaps within the education system, namely for refugee and immigrant youth. She lives in Boston.

Feifei (Shiyun) Hua is the co-founder of Eagle Online Learning Lab at Eagle Foreign Language Institute in Foshan, China. She worked with public schools in the area to provide low-cost and customized online learning experiences to underserved students. She is also passionate about advancing global citizenship education through Model United Nations. She served as the Secretary-General of the National High School Model United Nations Conference for three consecutive years. Feifei earned her Bachelor of Arts degree in International Development Studies from McGill University and has completed her graduate studies at the Harvard Graduate School of Education in International Education Policy. 
Maureen McNicholl is a certified middle school teacher and a career member of the U.S. Foreign Service of the U.S. Department of State where she manages global exchange programs to advance U.S. foreign policy goals through people-to-people diplomacy. The views expressed are her own and not necessarily those of the U.S. Government. Her experience spans public and private schools in the U.S. and in Europe. She holds master's degrees from Harvard University and Northwestern University and completed her undergraduate work at Boston College.

Sandra Ospina educational background is in science education. She has over a decade of experience teaching from nursery to college freshman. Sandra summarizes her top interests in education: global education, STEAM, lifelong learning, Neuroscience of learning, data, and personalization of learning. For the last seven years, she has been working in the Middle East and is inspired by the rapid and positive changes she has seen in the educational sector; she is excited to be part of that change as a leader and educator. She holds a B.S in Biology and Chemistry, a MA in Science Education, and she is currently doing a Master's in International Education Policy at the Harvard Graduate School of Education.

Open Access This chapter is licensed under the terms of the Creative Commons Attribution 4.0 International License (http://creativecommons.org/licenses/by/4.0/), which permits use, sharing, adaptation, distribution and reproduction in any medium or format, as long as you give appropriate credit to the original author(s) and the source, provide a link to the Creative Commons license and indicate if changes were made.

The images or other third party material in this chapter are included in the chapter's Creative Commons license, unless indicated otherwise in a credit line to the material. If material is not included in the chapter's Creative Commons license and your intended use is not permitted by statutory regulation or exceeds the permitted use, you will need to obtain permission directly from the copyright holder.

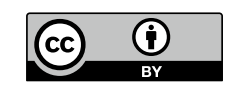

